\title{
Predicting spillover risk to non-target plants pre-release: Bikasha collaris a potential biological control agent of Chinese tallowtree (Triadica sebifera)
}

\author{
Gregory S. Wheeler ${ }^{1^{*}}$, James G. Duncan ${ }^{2}$, and Susan Wright ${ }^{2}$ \\ ${ }^{1}$ USDA/ARS Invasive Plant Research Lab, Ft Lauderdale, FL 33314 \\ ${ }^{2}$ USDA/ARS Invasive Plant Research Lab, Gainesville, FL 32608 \\ *Corresponding author: greg.wheeler@ars.usda.gov
}

Short title: Predicting spillover risk to non-target plants 


\begin{abstract}
Quarantine host range tests accurately predict direct risk of biological control agents to nontarget species. However, a well-known direct effect of biological control of weeds releases is spillover damage to non-target species. Spillover damage may occur when the population of agents achieves outbreak densities, depletes the target weed, and some feeding occurs on nontarget species. Similar to the assessment of direct risks to non-target species, we assessed the risk of spillover damage to non-target species pre-release. Quarantine experiments were conducted on the flea beetle Bikasha collaris (Coleoptera: Chrysomelidae), a potential biological control agent of Chinese tallowtree, Triadica sebifera, a weed of wetlands, forests, and natural areas in the southeastern U.S.A. Recently emerged, naïve B. collaris adults were fed leaves of $T$. sebifera (target species), three close relatives that are non-target species (Ditrysinia fruticosa, Gymnanthes lucida, Hippomane mancinella), or water. Adult longevity, egg production, and leaf damage were greatest on the weed and near zero or zero on the nontarget species and water control. A spillover event was simulated by transferring adults to nontarget species or water after feeding on $T$. sebifera for 2 or 4 weeks and found similar longevity and egg production as those fed only non-target species or water. These results indicated prerelease that when adults that have fed on $T$. sebifera are forced to spillover onto the non-target species, there is no risk of damage and that $B$. collaris will only be able to sustain populations on the target weed.
\end{abstract}

\title{
1. Introduction
}

Insect herbivores influence plant performance, regulate plant populations, and shape communities (Maron and Crone, 2006). Classical biological control of weeds, the deliberate introduction of exotic agents to control exotic invasive weeds, seeks to capitalize on these attributes while assisting in the restoration of invaded habitats. Biological control of weeds can be a cost-effective, self-sustaining means of controlling invasive species (van Wilgen et al., 2013). While a few authors have viewed the implementation of biological control of weeds with scepticism and described it as risky (Louda et al., 2003; Simberloff and Stiling, 1996), others claimed it is an underutilized tool that should play a larger role in the control of invasive 
species in natural areas (Seastedt, 2015). However, biological control should only be implemented with proper assessments of risks and benefits (Hinz et al., 2014; Pemberton, 2000).

Concerns for the safety of biological control focus on two key risks, direct effects where a potential agent may cause significant harm to non-target species and indirect effects where broader ecological impacts may occur (Fowler et al., 2012). These direct effects include transitory damage to non-target species upon which the agent is unable to complete development. Predictions of risks from direct effects are generally determined through nochoice starvation testing which distinguishes hosts from non-hosts (McClay and Balciunas, 2005; Van Klinken, 2000). Although this research has an excellent track record (Balciunas and Smith, 2006), it may overestimate host range and can produce false-positives, excluding otherwise safe agents (Van Klinken, 2000). An approved agent may exhibit a small amount of feeding on a non-target species, and this may be considered acceptable as the agent may be unable to complete development and sustain a population on any species but the target weed. Such direct effects may occur as transient damage in the form of spillover onto non-target species that grow in association with the weed. Distinguishing these short term ephemeral effects from more sustainable non-target damage would be helpful while making decisions prerelease about the relative risk of potential agents. Predicting both direct and indirect risks apriori is a major goal and challenge of weed biological control.

Spillover in weed biological control is a direct effect where a non-target is used after an agent builds up high numbers leading to the collapse of the target weed population (Schooler et al., 2003). While herbivores may commonly restrict their host range to sub-family taxa (e.g., genus) (Forister et al., 2015; Jaenike, 1990; Novotny and Basset, 2005; Novotny et al., 2002), strictly monophagous species may be only rarely available as biological control agents (Sheppard et al., 2005). Consequently, unintended short term spillover onto non-target species may occur especially when oligophagous agents become over abundant and decimate the target weed (Holt and Hochberg, 2001; Lynch et al., 2002). When discovered, this spillover may be of great concern (Dhileepan et al., 2006; Diehl and McEvoy, 1990; Johnson and Stiling, 1998; Rand and Louda, 2004; Stiling et al., 2004). Population outbreaks have been reported following 
initial release of host specific agents, however these effects are transitory and have not led to long term population level non-target impacts (Catton et al., 2015; Hoddle, 2004a; Hoddle, 2004b; Suckling and Sforza, 2014; Taylor et al., 2007).

Chinese tallow (Triadica sebifera (L.); hereafter 'tallow') is one of the most damaging invasive weeds in the southeastern U.S.A., impacting wetlands, forests, and natural areas (Bruce et al., 1997). Classical biological control research of tallow began in 2006 (Wheeler and Ding, 2014) with overseas and quarantine host testing studies resulting in a petition to regulatory authorities requesting field release of a flea beetle, Bikasha collaris (Baly) (Coleoptera: Chrysomelidae) (Huang et al., 2011; Wheeler et al., 2017).

The larvae and adults of $B$. collaris feed on tallow roots and leaves, respectively. The results of host range studies indicated a high degree of specificity where $B$. collaris was unable to sustain a population on any non-target species. However, adult no-choice tests showed a limited amount of foliage feeding on two related species of Euphorbiaceae, Ditrysinia fruticosa (Bartram) Govaerts \& Frodin and Gymnanthes lucida Sw. Oviposition by B. collaris only occurred on the target weed, tallow and on G. lucida where an average of 4.6 eggs (all nonviable) were produced (Wheeler et al., 2017). Another species of special concern was Hippomane mancinella L., a close relative of tallow and listed as endangered in Florida (Coile and Garland, 2003; Weaver and Anderson, 2010). Our host range research indicated little risk from direct effects by $B$. collaris on any of these non-targets. However, the risk of spillover damage onto non-targets after $B$. collaris had fed on tallow was unknown.

Results reported by Wheeler et al. (2017) indicated that, when B. collaris adults had fed on T. sebifera for two weeks, they were able to feed and had extended longevity on two nontarget species, $D$. fruticosa and G. lucida. Possibly, this feeding and extended longevity could be explained by the use of well-fed adults that had previously developed on their primary host on which they acquired sufficient resources to continue to feed after being switched to non-target plants. Thus, we predicted that adult feeding and longevity would decrease if adults were fed on these non-targets without the benefit of prior exposure to $T$. sebifera.

To examine the risk of spillover pre-release, we compared $B$. collaris adult performance when they were naive, or when they were fed tallow for 2 or 4 weeks and then switched to the 
non-targets in question. These responses were compared with adults fed continuously on tallow and also adults provided with water only. We determined the effects of these manipulations on adult feeding, longevity and oviposition to show pre-release to what extent $B$. collaris adults could spillover and cause significant and sustained damage on the non-target species.

\section{Methods and Materials}

\subsection{Insects}

In its native range, the flea beetle $B$. collaris has a temperate to subtropical distribution and was collected in Hubei, Ghizhou, Guangxi, and Hunan provinces ranging from latitudes $31.6^{\circ}$ to $24.8^{\circ}$ North. Quarantine colonies of $B$. collaris were initiated from two shipments made in November 2008 and October 2009 from Wuhan Botanical Garden, Wuhan, Hubei, China. Upon arrival in the US, the $B$. collaris collections were housed in the quarantine facility at the Invasive Plant Research Laboratory, USDA/ARS in Gainesville, FL where all of the studies were conducted. All of the colonies were rearedion live T. sebifera plants.

Bikasha collaris is a small beetle with adults about $2 \mathrm{~mm}$ long (Wheeler et al. 2017). Adults feed on young and old tallow leaves. In the laboratory females deposit eggs on multiple surfaces: leaves, stems, damp sand, cotton, and filter paper. In nature, females oviposit on the soil surface at the base of plants. The duration of the life cycle of $B$. collaris fed on $T$. sebifera under laboratory conditions was about 45 days from egg to adult, 9 days from egg to larva, 21 days from larva to pupation which lasted for 15 days before adult eclosion. Females began oviposition 17 days after eclosion and some continued to produce eggs for up to 6 months (Wheeler et al. 2017).

\subsection{Plants}

The Triadica taxon, is a small genus endemic to eastern and southeastern Asia (Esser, 2002). The closest relatives in North America are members of the same subtribe, Hippomaninae which 
include D. fruticosa, G. lucida, and $H$. mancinella (USDA/NRCS, 2016). Plants of $D$. fruticosa were collected at O' Leno State Park, Columbia Co, FL; H. mancinella were collected at the poisonous plant garden at the University of Florida, Ft Lauderdale, FL; and G. lucida were purchased at Mesozoic landscapes (Lake Worth, FL) and Plant Creations, Homestead, FL. Triadica sebifera plants were obtained from germinated seeds collected near Gainesville, FL.

\subsection{Adult threat of spillover damage to non-targets}

To test the prediction that $B$. collaris can survive on selected non-hosts if previously exposed to the primary host, $T$. sebifera, pairs of adults were placed in $30 \mathrm{ml}$ plastic cups with a layer of moistened sand $(10 \mathrm{ml})$ covered with a moistened $3.0 \mathrm{~cm}$ binder-free glass microfiber filter disc (Whatman ${ }^{\mathrm{TM}}$ Grade 934-AH). A tallow or test plant leaf was provided for food, the petiole of which was wedged between the side of the cup and the sand so that the leaf was positioned vertically. Cups were capped with plastic lids ventilated with a $6 \mathrm{~mm}$ central hole and plugged with a piece of absorbent cotton. Females oviposited on the filter paper, the leaves, and sides of the cups or between the filter paper and the sand. Twice each week adults were transferred to clean cups for egg production with fresh plant material. Old leaves were exchanged for fresh leaves between cup changes. Eggs were collected twice each week. Control adults continued to be monitored at least two weeks after all adults had died on non-target leaves.

To examine the potential for spillover damage by B. collaris, pairs of recently-emerged adults were placed in each container and fed tallow for different periods ( 0 (naïve), 2 , or 4 weeks) before they were switched to one of the non-target leaves. Following this switch female longevity (d), fecundity (number of eggs), and feeding damage $\left(\mathrm{mm}^{2}\right)$ were measured. Each plant species by feeding duration combination was replicated three times. The methods followed the standard protocols for adult no-choice tests conducted during previous host range determination (Wheeler et al., 2017). Feeding damage was determined by measuring area consumed after each test. Leaf area was measured $(40-140 \mathrm{X})$ with a portable digital microscope (IPM Scope Mega Pixel, Item No: 2860MP, Spectrum Technologies, Inc.). Each photographic image was processed with Adobe Photoshop Elements which converted the 
consumption results to $\mathrm{mm}^{2}$. We included the three non-target species $D$. fruticosa, $G$. lucida and $H$. mancinella. Additionally, a water only treatment, moistened dental wicks, was included to compare the nutritional value of each non-target leaf.

\subsection{Statistical analyses.}

To determine the effect of diet on naïve adults (prior to diet switching) we analyzed longevity, egg production and feeding for adults fed tallow, non-target species or water alone with a oneway ANOVA. The response data were checked for compliance with the assumptions of ANOVA and when necessary normality was improved with a log $(x+1)$ transformation (Sokal and Rohlf, 1981). To determine the effect of date of the diet switch (0, 2, or 4 weeks) and species (plant species or water alone) on B. collaris adult longevity, feeding and egg production, we used repeated measures analysis of variance (ANOVA). The PROC MIXED procedure was used in SAS with autoregressive order 1 covariance structure (SAS Institute, Inc., 2014), and when there was a significant date by species interaction the SLICE command was used to examine diet effects for each date separately. Specific comparisons were made using least significant differences (LSD) tests with the Tukey's adjustment $(P=0.05)$.

\section{Results}

3.1. Adult Longevity. Mean longevity was significantly greater for naïve $B$. collaris adult females fed tallow continuously compared with those fed only water or the leaves of non-target species $\left(F_{4,10}=15.87 ; P=0.0002\right)$ (Fig. 1). Naïve adult females (mean $\left.( \pm S E M)\right)$ fed tallow lived significantly longer (63.2 \pm 10.9 days) compared with those fed only water ( $2.3 \pm 0.3$ days), $D$. fruticosa (5.5 \pm 0.3 days), G. lucida ( $4.0 \pm 0.3$ days), or leaves of $H$. mancinella ( $8.3 \pm 6.1$ days) (Fig. 1). All naïve adults fed only water or non-target leaves from emergence lived less than 9 days and there was no significant difference in longevity among them (Fig. 1).

We found a significant date effect for longevity indicating that adult females previously fed tallow generally lived longer after being switched to water or the non-target species compared with naïve adults that did not have a previous tallow meal (Table 1). Additionally, a significant 
species effect was found where differences in longevity occurred among adult females switched to the different non-target species or water (Table 1). Longevity increased significantly only for adults switched from tallow after 4 weeks to $H$. mancinella compared with adults switched to water ( $P=0.0035$ by LSD tests) (Fig. 1). The interaction between date and species for longevity was not significant (Table 1).

3.2. Egg production. Mean egg production was significantly greater for naïve $B$. collaris adults fed tallow compared with those fed only water or the leaves of non-target species $\left(F_{4,10}\right.$ $=15.48 ; \mathrm{P}=0.0003)$ (Fig. 2). Adult females fed tallow leaves produced a mean ( \pm SEM) of $93.3( \pm$ 25.0) eggs. By contrast, no eggs were produced by naïve adults fed only water or each nontarget leaf.

Egg production by adults previously fed tallow for either 2 or 4 weeks was not significantly affected by switching from tallow to water or the non-target species (Fig. 2; Table 1). Moreover, the interaction between date and species for egg production was not significant (Table 1). Adults that were switched to water after 2 weeks and 4 weeks of feeding on tallow produced $7.7( \pm 7.7)$ and 0 eggs, respectively. The adults switched to $D$. fruticosa produced $9.7( \pm 9.7)$ eggs and $1.0( \pm 0.6)$ egg after previously fed tallow for 2 and 4 weeks, respectively. Those switched from tallow to G. lucida at 2 weeks produced 11.7 ( \pm 11.7 ) eggs per female and thereafter no additional eggs. The adults switched to $H$. mancinella after 2 and 4 weeks produced 0 and 5.0 ( \pm 5.0 ) eggs per female, respectively (Fig. 2).

3.3. Leaf damage. Mean leaf damage was significantly greater for naïve $B$. collaris adults fed tallow compared with those fed leaves of non-target species $\left(F_{3,8}=54.91 ; P<0.0001\right)$. Tallow leaf damage (mean $\left( \pm\right.$ SEM)) caused by naïve adults averaged $634.6( \pm 80.7) \mathrm{mm}^{2}$ (Fig. 3$)$. This damage was significantly greater than that of naïve adults fed the non-target species $D$. fruticosa $(32.6 \pm 22.5) \mathrm{mm}^{2}$, G. Iucida $(0 \pm 0) \mathrm{mm}^{2}$, or leaves of $H$. mancinella $(5.8 \pm 5.8) \mathrm{mm}^{2}$ (Fig. 3).

Leaf damage by adults was significantly affected only by the interaction of date and species (Table 1). Leaf damage comparisons among the non-targets were only significant for adults previously fed tallow for 2 weeks then switched to the non-targets (Table 1). However, 
individual comparisons (SLICE command in PROC MIXED) were not significant among the adults switched at 2 weeks from tallow to these non-targets. The adults switched after 2 weeks to $D$.

fruticosa caused $66.0( \pm 31.8) \mathrm{mm}^{2}$ leaf area damage, but adults switched to either G. lucida or H. mancinella did not feed (all $\mathrm{P}>0.13$ by LSD tests). Leaf damage of adults switched from tallow at 4 weeks was not significantly different among non-targets. This leaf damage to $D$. fruticosa was $46.5( \pm 17.9) \mathrm{mm}^{2}$, to $G$. lucida was $36.8( \pm 13.6) \mathrm{mm}^{2}$, and to $H$. mancinella was $11.5( \pm 11.4) \mathrm{mm}^{2}$ (Fig. 3).

\section{Discussion}

The results presented here confirm previous research which indicated that $B$. collaris will not sustain populations on the non-target species (Wheeler et al., 2017). Further, this study indicated that populations of $B$. collaris will not be sustained without continued access to the target weed. Our results showed that egg production is dependent upon sustained adult feeding on tallow leaves. Further, when fed tallow for 2 or 4 weeks and then switched to nontarget leaves, they produced no more eggs than those provided only water. If egg production occurs by naïve, tallow or non-target-fed adults, the larvae will not survive feeding on the roots of any other species except tallow (Wheeler et al., 2017). In order for a B. collaris population to be sustained, tallow will have to be growing in close proximity to the non-targets. Of these nontargets, $D$. fruticosa is the species most vulnerable to spillover damage as it is the only species tested here that has an overlapping distribution with tallow (EddMapS, 2016; USDA/NRCS, 2016).

Spillover damage in biological control of weeds to non-target plants is generally considered a transient event, i.e. temporary and following the depletion of the target weed (Sheppard et al., 2005; Thomas et al., 2004). This typically occurs following large population outbreaks of agents, and damage to non-targets is greatest where the geographic range of the weed and non-target overlap (Taylor et al., 2007). However, sustained damage may occur to non-targets when the weed and non-targets are sympatric (Rand and Louda, 2004). For example, Chrysolina quadrigemina Suffrian (Coleoptera: Chrysomelidae) introduced in the western U.S.A. for biological control of invasive St. Johnswort, Hypericum perforatum L. impacts 
a native species $H$. punctatum Lam. in the eastern U.S.A. Through feeding most vigorously in sunny exposed plants, the biological control agent influences the spatial distribution of the native, $H$. punctatum where it occurs along forest edges despite its higher performance in open habitats (Tingle et al., 2016).

Our results indicate that $B$. collaris adults, without a previous tallow meal, survived for a few days and caused a small amount of feeding damage (i.e. nibbling) when switched to the non-target species. Possibly the handling of the adults to conduct this host switch decreased longevity, egg production and feeding but this seems highly unlikely. Compared with damage to tallow, feeding of $D$. fruticosa (7\% of tallow damage), G. lucida (6\% of tallow damage), and $H$. mancinella ( $1 \%$ of tallow damage) was significantly reduced. In a spillover scenario, after the adults feed on tallow and deplete this as a food source, longevity on $\mathrm{H}$. mancinella (after 4 weeks tallow feeding) increased slightly but no significant feeding damage occurred. We suspect that the increased longevity on $H$. mancinella, without apparent simultaneous feeding, was due to $B$. collaris consumption of extrafloral nectar produced by this species (Koptur, 1992). These EFN secretions are a plant defense produced constitutively and in response to herbivory that provide nutrients to predators and parasitoids (Heil, 2015). Extrafloral nectar may provide short term nutrition to herbivores as they contain sugars, amino acids and other nutrients (Baker and Baker, 1973; Bentley, 1977). Although we have not seen herbivores feeding at extrafloral nectar of $H$. mancinella, herbivores have been known to exploit these resources (DeVries and Baker, 1989).

Previous experience and the physiology of herbivores can be important factors that influence host plant discrimination during feeding and oviposition (Bernays and Chapman, 1994). Several factors including food deprivation and egg load have been shown to influence the acceptance of host plant species (Barton-Browne, 1993; Dethier, 1982). Some herbivorous insects become less selective with increased host deprivation (Fitt, 1986; Horton and Krysan, 1991; Roitberg and Prokopy, 1983; Singer, 1982). Herbivorous insects developed for biological control of weeds may be more accepting of non-target species when deprived of the target weed (Withers, 1997). The results of $B$. collaris presented here showed that food deprivation had no effect on host selection. Both naïve adults and those that were switched from tallow to 
non-target species experienced a period of brief food deprivation. However, adult B. collaris deprived of tallow either when recently emerged, or after 2 or 4 weeks of feeding on their host, did not change acceptance of the non-host species tested here for feeding or oviposition. Tallow-fed adults, after being switched to water or the non-targets, were able to live a few days but this was apparently due only to the reserves derived from previous tallow meals. Thus for B. collaris adults, acceptance of the non-targets for feeding and oviposition did not change with food deprivation.

The spillover effects of biological control agents have been discussed by several researchers (Fowler et al., 2012; Thomas et al., 2004) but mostly examined in post-release studies (Blossey et al., 2001; Catton et al., 2015; Dhileepan et al., 2006; Lake et al., 2015; Schooler et al., 2003; Tingle et al., 2016). Notable exceptions were field studies conducted on one continent (e.g., Africa) to assist in the decision to release on another continent (e.g., North America) (Center and Hill, 2002; Coetzee et al., 2009). Additionally, a simulation model was developed a-priori to predict the risks and benefits, including spillover events associated with the release of a specialist herbivore (Raghu et al., 2007). A method that predicts risk of spillover prior to release, has obvious benefits. The research presented here was conducted during quarantine host testing and allows for a prediction of spillover damage to non-targets by a potential agent being considered for release. The ability to make these pre-release predictions of non-target effects are high priorities for the development of safe biological control agents (Hopper, 2001). Our results indicate that the risk of spillover damage to non-target species by the potential tallow biological control agent $B$. collaris is highly unlikely as the adults are unable to feed and exploit other species to complete their life cycle. 


\section{Acknowledgements}

We thank Lollis, J.A., Steininger, M. S., (USDA-ARS-IPRL) for technical assistance and J. Ding (Chinese Academy of Science) for field assistance. Additionally, voucher collections of these flea beetles are deposited in US National Museum, Washington DC; Entomology Department, and the Florida State Collection of Arthropods, Gainesville, FL. Our quarantine collections were identified morphologically by Dr. Alexander S. Konstantinov, Systematic Entomology Laboratory, National Museum of Natural History, Washington, DC, USA. The importation permit to the U.S.A. was issued by the United States Department of Agriculture, Animal and Plant Health Inspection Service to G. Wheeler (Permits P526P-07-06600 and P526P-09-02373). This project was partially funded by the Florida Fish and Wildlife Conservation Commission (\#08250, TA:088), the South Florida Water Management District (\#4600001427), and the United States Department of Agriculture, Agricultural Research Service. 
Figure captions:

Fig. 1. Mean ( \pm SEM) longevity of adult Bikasha collaris flea beetles when fed tallow, water only, or switched from tallow to different species at different intervals (0,2, or 4 weeks). Means with the same letters, within a time interval, were not significantly different according to a LSD with Tukey's adjustment $(P=0.05)$. ns: not significant.

Fig. 2. Mean ( \pm SEM) egg production of adult Bikasha collaris flea beetles when fed tallow only, water, or tallow and then switched to different species or water at different intervals $(0,2$, or 4 weeks). Means with the same letters, within a time interval, were not significantly different according to a LSD with Tukey's adjustment $(P=0.05)$. ns: not significant.

Fig. 3. Mean ( \pm SEM) leaf damage $\left(\mathrm{mm}^{2}\right)$ of adult Bikasha collaris flea beetles when fed tallow only, water, or tallow and then switched to different species at different intervals $(0,2$, or 4 weeks). Means with the same letters, within a time interval, were not significantly different according to a LSD with Tukey's adjustment $(P=0.05)$. ns: not significant. 


\section{References}

Baker, H.G., Baker, I., 1973. Amino-acids in nectar and their evolutionary significance. Nature $241,543-545$.

Balciunas, J., Smith, L., 2006. Prerelease efficacy assessment, in quarantine, of a tephritid gall fly being considered as a biological control agent for Cape-ivy (Delairea odorata). Biol. Control $39,516-524$.

Barton-Browne, L., 1993. Physiologically induced changes in resource-oriented behavior. Annu. Rev. Entomol. 38, 1-25.

Bentley, B.L., 1977. Extrafloral nectaries and protection by pugnacious bodyguards. Annu. Rev. Ecol. Syst. 8, 407-427.

Bernays, E.A., Chapman, R.F., 1994. Host-Plant Selection by Phytophagous Insects. Chapman \& Hall, New York.

Blossey, B., Casagrande, R., Tewksbury, L., Landis, D.A., Wiedenmann, R.N., Ellis, D.R., 2001. Nontarget feeding of leaf-beetles introduced to control purple loosestrife (Lythrum salicaria L.). Nat. Area J. 21, 368-377.

Bruce, K.A., Cameron, G.N., Harcombe, P.A., Jubinsky, G., 1997. Introduction, impact on native habitats, and management of a woody invader, the Chinese tallow tree, Sapium sebiferum (L.) Roxb. Nat. Area J. 17, 255-260.

Catton, H.A., Lalonde, R.G., De Clerck-Floate, R.A., 2015. Nontarget herbivory by a weed biocontrol insect is limited to spillover, reducing the chance of population-level impacts. Ecol. Appl. 25, 517-530.

Center, T.D., Hill, M.P., 2002. Field efficacy and predicted host range of the pickerelweed borer, Bellura densa, a potential biological control agent of water hyacinth. Biocontrol 47, 231243.

Coetzee, J.A., Byrne, M.J., Hill, M.P., Center, T.D., 2009. Should the mirid, Eccritotarsus catarinensis (Heteroptera: Miridae), be considered for release against water hyacinth in the United States of America? Biocontrol Sci. Tech. 19, 103-111.

Coile, N.C., Garland, M.A., 2003. Notes on Florida's Endangered and Threatened Plants. Division of Plant Industry, Florida Department of Agriculture \& Consumer Services, Gainesville, FL. 
Dethier, V.G., 1982. Mechanism of host-plant recognition. Entomol. Exp. Appl. 31, 49-56.

DeVries, P.J., Baker, I., 1989. Butterfly exploitation of an ant-plant mutualism: adding insult to herbivory. J. N. Y. Entomol. Soc. 97, 332-340.

Dhileepan, K., Trevino, M., Raghu, S., 2006. Temporal patterns in incidence and abundance of Aconophora compressa (Hemiptera: Membracidae), a biological control agent for Lantana camara, on target and nontarget plants. Environ. Entomol. 35, 1001-1012.

Diehl, J.W., McEvoy, P.B., 1990. Imact of cinnabar moth (Tyria jacobaeae) on Senecio triangularis, a non-target native plant in Oregon. In: Delfosse, E.S. (Ed.). Proceedings VII International Symposium Biological Control of Weeds, Rome, Italy, pp. 119-126.

EddMapS, 2016. Early Detection and Distribution Mapping System. Available from http://www.eddmaps.org, July 11, 2016.

Esser, H.J., 2002. A revision of Triadica Lour. (Euphorbiaceae). Harvard Pap. Bot. 7, 17-21.

Fitt, G.P., 1986. The influence of a shortage of hosts on the specificity of oviposition behaviour in species of Dacus (Diptera, Tephritidae). Physiol. Entomol. 11, 133-143.

Forister, M.L., Novotny, V., Panorska, A.K., Baje, L., Basset, Y., Butterill, P.T., Cizek, L., Coley, P.D., Dem, F., Diniz, I.R., Drozd, P., Fox, M., Glassmire, A.E., Hazen, R., Hrcek, J., Jahner, J.P., Kaman, O., Kozubowski, T.J., Kursar, T.A., Lewis, O.T., Lill, J., Marquis, R.J., Miller, S.E., Morais, H.C., Murakami, M., Nickel, H., Nicholas, P., Ricklefs, R.E., Singer, M.S., Smilanich, A.M., Stireman, J.O., Villamarin-Cortez, S., Vodka, S., Volf, M., Wagner, D.L., Walla, T., Weiblen, G.D., Dyer, L.A., 2015. The global distribution of diet breadth in insect herbivores. Proc. Nat. Acad. Sci. 112, 442-447.

Fowler, S.V., Paynter, Q., Dodd, S., Groenteman, R., 2012. How can ecologists help practitioners minimize non-target effects in weed biocontrol? J. Appl. Ecol. 49, 307-310.

Heil, M., 2015. Extrafloral nectar at the plant-insect interface: a spotlight on chemical ecology, phenotypic plasticity, and food webs. Annu. Rev. Entomol. 60, 213-232.

Hinz, H.L., Schwarzländer, M., Gassmann, A., Bourchier, R.S., 2014. Successes we may not have had: a retrospective analysis of selected weed biological control agents in the United States. Invasive Plant Sci. Manag. 7, 565-579. 
Hoddle, M.S., 2004a. Restoring balance: using exotic species to control invasive exotic species Conserv. Biol. 18, 38-49.

Hoddle, M.S., 2004b. The strength of biological control in the battle against invasive pests: a reply. Conserv. Biol. 18, 61-65.

Holt, R.D., Hochberg, M.E., 2001. Indirect Interactions, Community Modules and Biological Control: a Theoretical Perspective In: Wajnberg, E., Scott, J.K., Quimby, P.C. (Eds.), Evaluating Indirect Ecological Effects of Biological Control. CAB International, pp. 13-37. Hopper, K.R., 2001. Research needs concerning non-target impacts of biological control introductions. In: Wajnberg, E., Scott, J.K., Quimby, P.C. (Eds.), Evaluating indirect ecological effects of biological control CABI Publishing, Wallingford, New Zealand, pp. 3956.

Horton, D.R., Krysan, J.L., 1991. Host acceptance behavior of pear psylla (Homoptera: Psyllidae) affected by plant species, host deprivation, habituation, and egg-load. Ann. Entomol. Soc. Am. 84, 612-627.

Huang, W., Wheeler, G.S., Purcell, M.F., Ding, J., 2011. The host range and impact of Bikasha collaris (Coleoptera: Chrysomelidae), a promising candidate agent for biological control of Chinese tallow, Triadica sebifera (Euphorbiaceae) in the United States. Biol. Control 56, 230-238.

SAS Institute, Inc. 2014. SAS/STAT User's Guide, Release 9.3. SAS Institute, Cary, NC. Jaenike, J., 1990. Host specialization in phytophagous insects. Annu. Rev. Ecol. Syst. 21, 243273.

Johnson, D.M., Stiling, P., 1998. Distribution and dispersal of Cactoblastis cactorum (Lepidoptera: Pyralidae), an exotic Opuntia - feeding moth, in Florida. Florida Entomol. 81, $12-22$.

Koptur, S., 1992. Plants with extrafloral nectaries and ants in Everglades habitats. Florida Entomol. 75, 38-50.

Lake, E.C., Smith, M.C., Dray, F.A., Pratt, P.D., 2015. Ecological host-range of Lilioceris cheni (Coleoptera: Chrysomelidae), a biological control agent of Dioscorea bulbifera Biol. Control $85,18-24$. 
Louda, S.M., Pemberton, R.W., Johnson, M.T., Follett, P.A., 2003. Nontarget effects-the Achilles' heel of biological control? Retrospective analyses to reduce risk associated with biocontrol introductions. Annu. Rev. Entomol. 48, 365-396.

Lynch, L.D., Ives, A.R., Waage, J.K., Hochberg, M.E., Thomas, M.B., 2002. The risks of biocontrol: transient impacts and minimum nontarget densities. Ecol. Appl. 12, 1872-1882.

Maron, J.L., Crone, E., 2006. Herbivory: effects on plant abundance, distribution and population growth. Proc. R. Soc. B 273, 2575-2584.

McClay, A.S., Balciunas, J.K., 2005. The role of pre-release efficacy assessment in selecting classical biological control agents for weeds - Applying the Anna Karenina principle. Biol. Control 35, 197-207.

Novotny, V., Basset, Y., 2005. Host specificity of insect herbivores in tropical forests. Proc. R. Soc. B 272, 1083-1090.

Novotny, V., Basset, Y., Miller, S.E., Weiblen, G.D., Bremer, B., Cizek, L., Drozd, P., 2002. Low host specificity of herbivorous insects in a tropical forest. Nature $416,841-844$.

Pemberton, R.W., 2000. Predictable risk to native plants in weed biological control. Oecologia $125,489-494$.

Raghu, S., Dhileepan, K., Scanlan, J.C., 2007. Predicting risk and benefit a priori in biological control of invasive plant species: A systems modelling approach. Ecol. Model. 208, 247-262.

Rand, T.A., Louda, S.M., 2004. Exotic weed invasion increases the susceptibility of native plants to attack by a biocontrol herbivore. Ecology $85,1548-1554$.

Roitberg, B.D., Prokopy, R.J., 1983. Host deprivation influence of Rhagoletis pomonella to its oviposition deterring pheromone. Physiol. Entomol. 8, 69-72.

Schooler, S.S., Coombs, E.M., McEvoy, P.B., 2003. Nontarget effects on crepe myrtle by Galerucella pusilla and G. calmariensis (Chrysomelidae), used for biological control of purple loosestrife (Lythrum salicaria). Weed Sci. 51, 449-455.

Seastedt, T.R., 2015. Biological control of invasive plant species: a reassessment for the Anthropocene. New Phytol. 205, 490-502.

Sheppard, A.W., Van Klinken, R.D., Heard, T.A., 2005. Scientific advances in the analysis of direct risks of weed biological control agents to nontarget plants. Biol. Control 35, 215-226. 
Simberloff, D., Stiling, P., 1996. How risky is biological control? Ecology 77, 1965-1974.

Singer, M.C., 1982. Quantification of host preference by manipulation of oviposition behavior in the butterfly Euphydryas editha. Oecologia 52, 224-229.

Sokal, R.R., Rohlf, F.J., 1981. Biometry: The Principles and Practice of Statistics in Biological Research. Freeman and Co, New York.

Stiling, P., Moon, D., Gordon, D., 2004. Endangered cactus restoration: mitigating the nontarget effects of a biological control agent (Cactoblastis cactorum) in Florida. Restoration Ecol. 12, 605-610.

Suckling, D.M., Sforza, R., 2014. What magnitude are observed non-target impacts from weed biocontrol? PLoS ONE 9, e84847.

Taylor, D.B.J., Heard, T.A., Paynter, Q., Spafford, H., 2007. Nontarget effects of a weed biological control agent on a native plant in Northern Australia. Biol. Control 42, 25-33.

Thomas, M.B., Casula, P., Wilby, A., 2004. Biological control and indirect effects. Trend. Ecol. Evol. 19, 61-61.

Tingle, J.L., Cook-Patton, S.C., Agrawal, A.A., 2016. Spillover of a biological control agent (Chrysolina quadrigemina) onto native St. Johnswort (Hypericum punctatum). PeerJ 4, e1886.

USDA/NRCS, 2016. The PLANTS Database. National Plant Data Center. Available from http://plants.usda.gov, Baton Rouge, LA., July 11, 2016

Van Klinken, R.D., 2000. Host specificity testing: why do we do it and how we can do it better. In: Van Driesche, R.G., Heard, T.A., McClay, A., Reardon, R. (Eds.), Proceedings: Host Specificity Testing of Exotic Arthropod Biological Control Agents: The Biological Basis for Improvement in Safety. USDA Forest Service, Morgantown, WV, pp. 54-68.

van Wilgen, B.W., Moran, V.C., Hoffmann, J.H., 2013. Some perspectives on the risks and benefits of biological control of invasive alien plants in the management of natural ecosystems. J. Environ. Manage. 52, 531-540.

Weaver, R.E., Anderson, P.J., 2010. Notes on Florida's endangered and threatened plants. Division of Plant Industries. Florida Department of Agriculture and Consumer Services, Bureau of Entomology, Nematology and Plant Pathology - Botany Section. 
Wheeler, G.S., Ding, J., 2014. Is Chinese Tallowtree, Triadica sebifera, an appropriate target for biological control in the United States? Invasive Plant Sci. Manag. 7, 345-359.

Wheeler, G.S., Steininger, M.S., Wright, S.A., 2017. Quarantine host range of Bikasha collaris; A potential biological control agent of Chinese tallowtree (Triadica sebifera) in North America. Entomol. Exper. Appl. In press.

Withers, T.M., 1997. Changes in plant attack over time in no-choice tests: an indicator of specificity. N. Z. Plant Prot. 50, 214. 
Table 1. Statistics from ANOVA accessing effects of date of Bikasha collaris switch from tallow to the non-target, species including water, the weed Triadica sebifera, and non-targets Ditrysinia fruticosa, Gymnanthes lucida, and Hippomane mancinella. Significant $P$ values are in bold.

$\begin{array}{lrrr}\text { Effect } & \text { df } & \text { F } & \text { P } \\ \text { Longevity } & & & \\ \text { Date (D) } & 2 & 17.31 & <\mathbf{0 . 0 0 0 1} \\ \text { Species (S) } & 3 & 9.4 & \mathbf{0 . 0 0 5 3} \\ \text { D* S } & 6 & 1.29 & 0.3160 \\ & & & \\ \text { Egg production } & & & \\ \text { Date (D) } & 2 & 2.28 & 0.1348 \\ \text { Species (S) } & 3 & 0.11 & 0.949 \\ \text { D * S } & 6 & 0.56 & 0.7585 \\ & & & \\ \text { Leaf damage } & & & \\ \text { Date (D) } & 2 & 2.21 & 0.1525 \\ \text { Species (S) } & 2 & 3.15 & 0.1163 \\ \text { D * S } & 4 & 3.92 & \mathbf{0 . 0 2 9 2} \\ \text { Species at 0 weeks } & 2 & 1.34 & 0.2992 \\ \text { Species at 2 weeks } & 2 & 6.43 & \mathbf{0 . 0 1 2 6} \\ \text { Species at 4 weeks } & 2 & 1.45 & 0.2725 \\ & & & \end{array}$




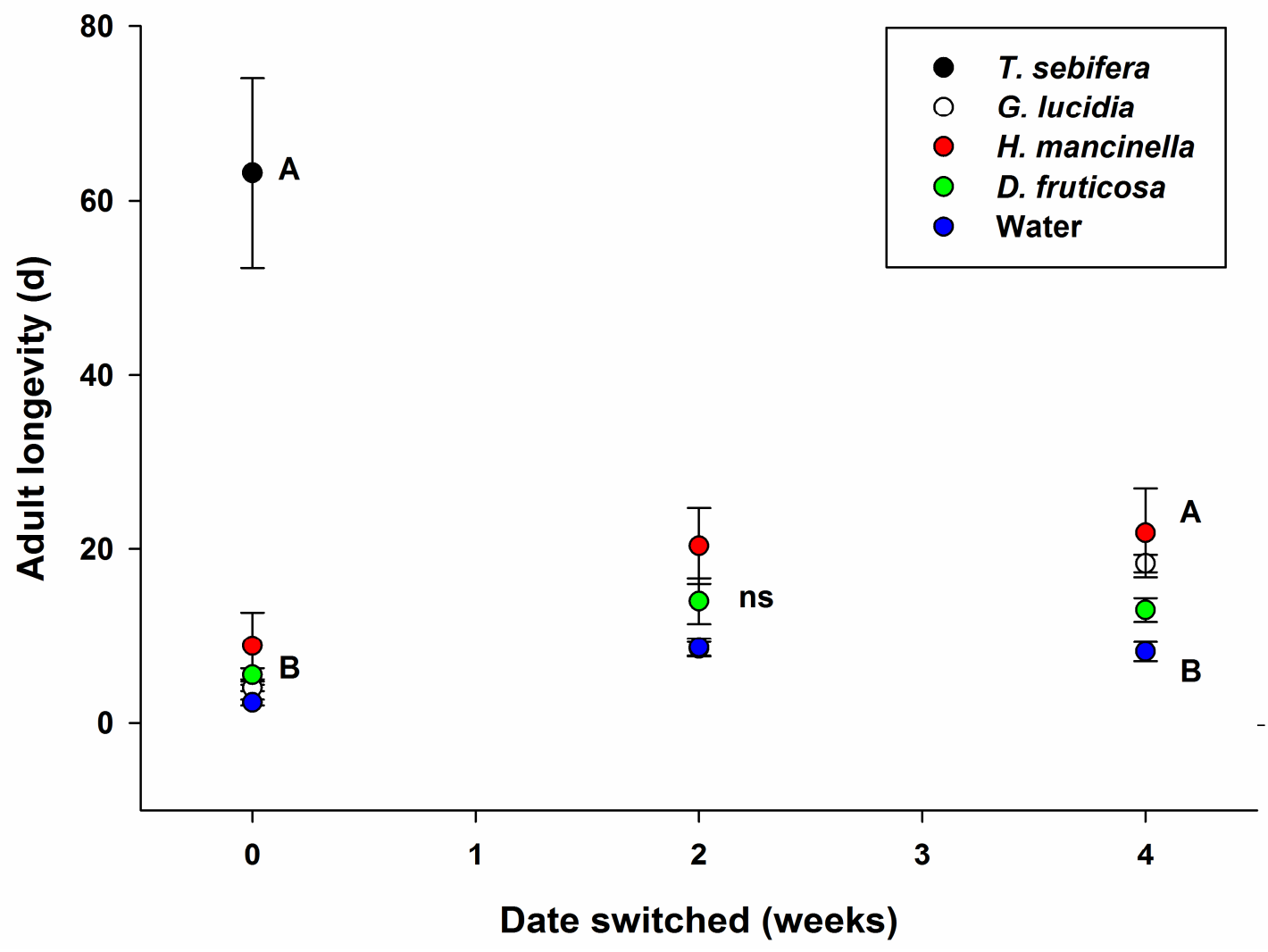




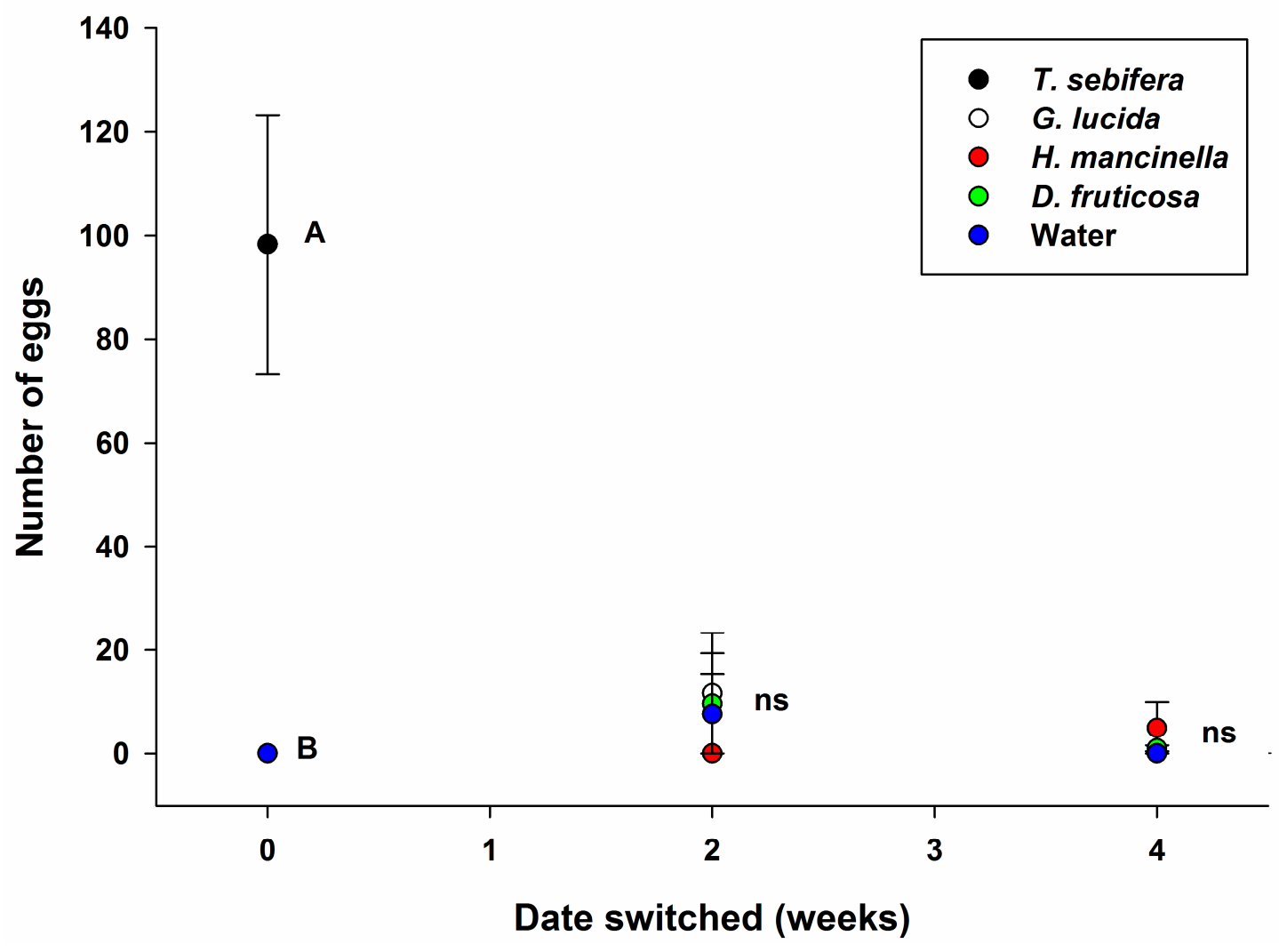




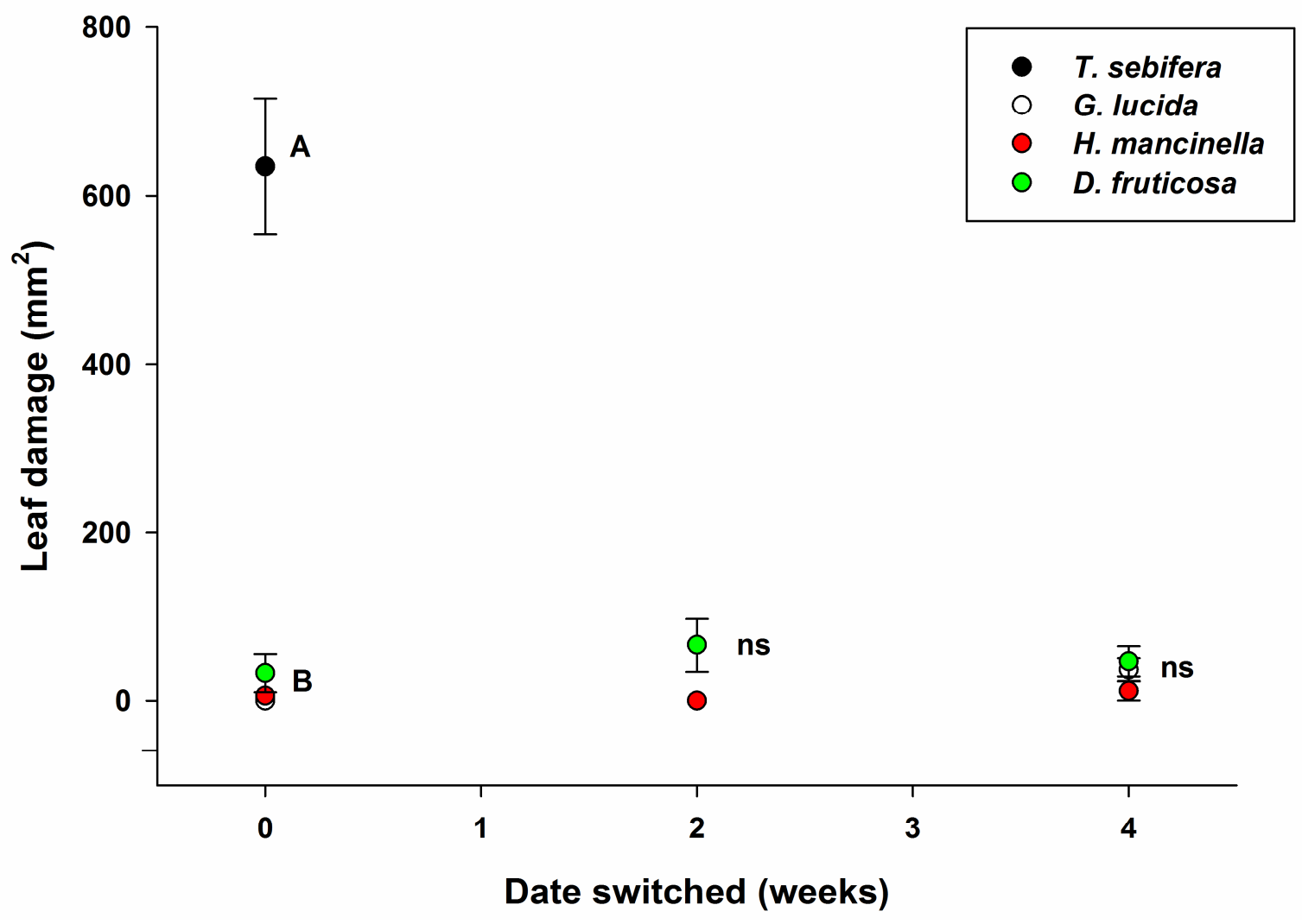



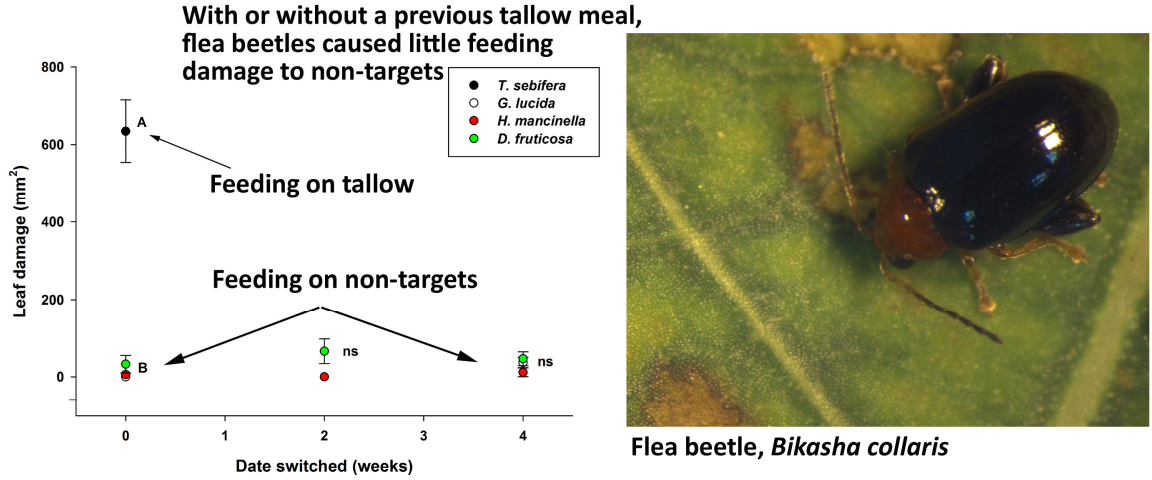

Flea beetle, Bikasha collaris

Graphical abstract 